\title{
Prepubertal Vaginal Bleeding with a Rare Etiology
}

\author{
Deepti Jain ${ }^{1 *}$ and Shikha Khandelwal ${ }^{2}$ \\ ${ }^{1}$ Consultant Gynecologist, Chhotu Ram Hospital Rohtak, India \\ ${ }^{2}$ Department of Paediatrics, Ram Manohar Lohia Hospital, India
}

Submission: April 12, 2017; Published: May 23, 2017

*Corresponding author: Deepti Jain, Consultant Gynecologist. Chhotu Ram Hospital Rohtak , Haryana , India, Email: deeptijain62@gmail.com

Abstract

A 6 year old girl presented with vaginal bleeding for the last one and a half month.. There was no history suggestive of trauma or molestation. Adrenarche or the larche was not present and her height and weight plotted in the growth chart showed normal growth. Investigations revealed no benign or malignant neoplasm of the ovaries or in vagina or cervix. Thyroid stimulating hormone was in the normal range and low levels of luteinising hormone were seen. A coagulation profile revealed raised activated partial thromboplastin time and decreased levels of factor V1. A short course of vitamin $\mathrm{K}$ and tranexemic acid was given. The bleeding stopped after 5 days, thus confirming that vaginal bleeding was related to deficiency of factor V111. Von wille brand factor Ag was in the normal range confirming haemophilia A, a rare cause of prepubertal vaginal haemorrhage and a very rare haematologic disorder seen in females.

Keywords: Activated partial thromboplastin time (APTT); Haemophilia; Von wille brand factor antigen (vWF Ag); Thyroid stimulating hormone (TSH)

\section{Introduction}

Prepubertal vaginal bleeding is a scary riddle both for the paediarician and the gynaecologist. This girl presented with prepubertal vaginal bleeding and was found to have a very rare haematological disorder causing bleeding per vaginum.

\section{Case Report}

A 6 year old girl presented on July 1, 2014 with vaginal bleeding for last 45 days. There was no history of bleeding from any other part of the body. History of insertion of foreign body in the vagina, or trauma to the genital area including sexual molestation was denied by the child's parents.

The girl weighed $23.5 \mathrm{~kg}$ and her height was 137 centimeters falling in the normal range of growth curve. There was no breast development i.e. Tanner stage 1 and no axillary or pubic hair.

On examination, there was soreness and redness on the vulva in an elliptical zone all around the introitus. Hymen was intact with a normal hymenal opening. The clitoris appeared normal. The urethral opening was normal with no protrusion of mucosa. A diagnosis of monilial vulvovaginitis was considered. The girl was given a local cream containing steroid and clotrimazole.

After 3 days the redness on vulva had decreased but the panty liner was soaked with blood confirming bleeding per vaginum. Ultrasonography showed that the uterus was of prepubertal size.
Endometrium was not defined and there was no adnexal mass (Table 1).

Table 1:

\begin{tabular}{|c|c|c|}
\hline & Patient Values & Normal Range \\
\hline Haemoglobin & $11.80 \mathrm{~g} / \mathrm{dl}$ & $11.00-14.00 \mathrm{~g} / \mathrm{dl}$ \\
\hline Platelet count & 260 thousand $/ \mathrm{mm}^{3}$ & $\begin{array}{l}150-490 \text { thousand/ } \\
\mathrm{mm}^{3}\end{array}$ \\
\hline Total leucocyte count & 8.40 thousand $/ \mathrm{mm}^{3}$ & $\begin{array}{c}5.00-15.00 \\
\text { thousand } / \mathrm{mm}^{3}\end{array}$ \\
\hline TSH & $1.22 \mathrm{~m} \mathrm{iu} / \mathrm{ml}$ & $0.5-5 \mathrm{~m} \mathrm{iu} / \mathrm{ml}$ \\
\hline Alkaline phosphatase & $39.62 \mathrm{~m} \mathrm{iu} / \mathrm{ml}$ & $5-40 \mathrm{miu} / \mathrm{ml}$ \\
\hline $\begin{array}{l}\text { Serum glutamate } \\
\text { transferase }\end{array}$ & $26.52 \mathrm{~m} \mathrm{iu} / \mathrm{ml}$ & 5-40 mi.u/l \\
\hline $\begin{array}{c}\text { Follicle stimulating } \\
\text { hormone }\end{array}$ & $1.53 \mathrm{~m} \mathrm{iu} / \mathrm{ml}$ & $1.00-10.80 \mathrm{miu} / \mathrm{ml}$ \\
\hline $\begin{array}{c}\text { International } \\
\text { normalized ratio } \\
\text { (INR) }\end{array}$ & 1.04 & $1-1.5$ \\
\hline Luteinising hormone & $<0.07 \mathrm{~m} \mathrm{iu} / \mathrm{ml}$ & $0.02-0.18 \mathrm{miu} / \mathrm{ml}$ \\
\hline Blood Sugar(R) & $122 \mathrm{mg} / \mathrm{dl}$ & upto $140 \mathrm{mg} / \mathrm{dl}$ \\
\hline APTT & $49.00 \mathrm{sec}$ & 29.74-40.50 Sec \\
\hline Factor VIII & $36 \%$ & $60-150 \%$ \\
\hline Factor IX & $66.20 \%$ & $70-120 \%$ \\
\hline VWF Ag & $102 \%$ & $50 \%-160 \%$ \\
\hline
\end{tabular}


Vaginoscopy was done with a fine endoscope which revealed that the vaginal mucosa was friable and congested, but no growth or polyp was seen.

A coagulation profile showed an abnormal APTT and a deficiency of factor V111. VWF Ag was in the normal range (Figure 1).

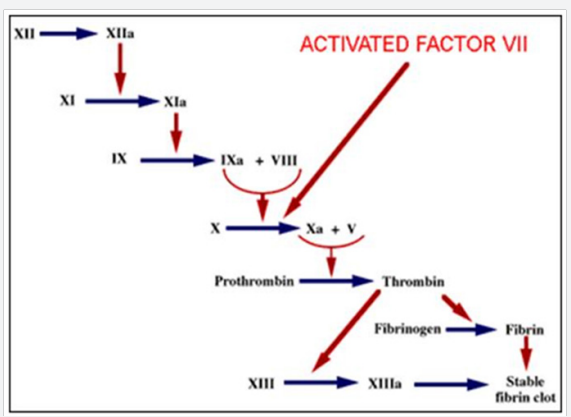

Figure 1: Coagulation cascade showing intrinsic pathway.

\section{Differential Diagnosis}

As the girl was of average height and weight and there was no adrenarche or thelarche with a normal prepubertal luteinising and follicle stimulating hormone; precocious puberty was ruled out. Urethral mucosal prolapse was not present on local examination. A normal total leucocyte count, suggested thar genital infection was not responsible for the vaginal bleeding.

Vaginoscopy showed the absence of a neoplasm of cervix and vagina. An ultrasonogram performed in this case excluded an ovarian neoplasm. Ovarian neoplasms like follicular ovarian cysts, granulose cell tumour and endodermal sinus tumour may present rarely, secreting excess estrogens and causing endometrial proliferation and bleeding.

A normal TSH confirmed the absence of hypothyroidism. A thin endometrium ruled out endogenous or exogenous estrogen exposure.

An abnormal APTT and deficiencies of Factor VIII and Factor IX made us think of a probability of dysfunction in blood coagulation in the intrinsic arm of coagulation cascade (Figure 1).
a. A prolonged APTT.
b. Normal prothrombin time.
c. Normal platelet count ,
d. Deficiency of factor V111.
e. Von Wille brand factor in the normal range.

The above findings in the coagulation profile led us to the final diagnosis I.e. Prepubertal vaginal haemorrhage owing to mild haemophilia (mild as Factor V111i is between 5\%$40 \%)$.

\section{Treatment}

The girl was given injection vitamin $\mathrm{K} 5 \mathrm{mg}$ daily for 3 days, tablet tranexemic acid $250 \mathrm{mg}$ twice daily for 3 days and a haematinic. After 5 days, the bleeding which had continued for 2months finally stopped.

A repeat episode of bleeding after two months, in the form of epistaxis led to the confirmation of the diagnosis of haemophilia.

\section{Discussion}

Prepubertal vaginal bleeding is a rare disorder and Heller was the first to report this condition [1].

In a study of a 5 year period in which charts of 1057 young girls were evaluated for precocious puberty, only 24 girls i.e. $2.3 \%$ had benign prepubertal vaginal bleeding [2].

Vaginal bleeding prior to puberty has been reported in a girl with acquired primary hypothyroidism where the body mass index was $25.9 \mathrm{~kg} / \mathrm{m}^{2}$ and TSH more than $150 \mu / \mathrm{l}$ [3].

Urethral prolapse was found in 50\% girls with premenarcheal genital bleeding in one study [4].

In this girl vaginal bleeding occurred because of factor V111 deficiency i.e. haemophilia A. Haaemophilia A is an X linked recessive disorder listed in the Orphanet journal of rare diseases [5].

It has an incidence of 1 in 5000 in males. Females are carriers of the disease and are generally not affected. Rare cases of haemophilia have been described in females, when a carrier female marries a haemophilic male or because of denovo mutations in one or both $\mathrm{X}$ chromosomes; although very rare $[6,7]$.

Consanguineous marriage was found as a cause of occurrence of haemophilia in a woman in one report [7]. However in our patient consanguinity was not seen and a male sibling does not have haemophilia.

\section{Conclusion}

Prepubertal vaginal bleeding is very distressing for the girl child and should be diagnosed by following a stepwise algorithm. The cause once dillineated, should be treated urgently to prevent complications. A careful follow up is a must for repeat episodes, especially in case of haematologic disorders.

\section{References}

1. Heller Me, Dewhurst, grant DB (1979) Premature menarche without the evidence of precocious puberty. Arch Dis Child jun 54(6): 472-475.

2. Nella AA, Kaplowitz PB, Ramnitz MS, Nandagopal R (2014) Benign vaginal bleeding in 24 prepubertal patients: clinical , biochemical and imaging features, J Pediatr Endocr 27(9-10): 821-825.

3. Wormsbecker A, Clarson C (2010) Acquired Primary Hypothyroidism: vaginal bleeding in a quiet child. CMAJ 182(6): 588- 590. 
4. Ugboma HA, Ugboma EW (2007) Genital bleeding in Premenarcheal girls. Port Harour Medical Journal 1: 186-189.

5. Franchini M, Mannucci PM (2012) Past, present and future of haemophilia: a narrative review. Orphanet Journal of Rare Diseases 7: 24 .

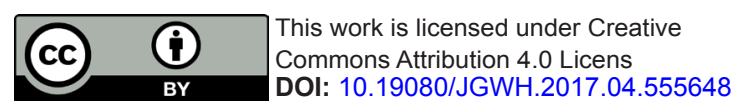

6. Pavlova A, Brondke H, Musebeck H, Pollman H, Srivastava A, et al. (2009) Molecular mechanisms underlying hemophilia phenotype in seven females: J Thrombo Haemost 7: 976-982.

7. Nair PS, Shetty S, Ghosh KA (2012) homozygous female haemophilia A. Indian J Hum Genet 18(1): 134-136.

\section{Your next submission with Juniper Publishers will reach you the below assets}

- Quality Editorial service

- Swift Peer Review

- Reprints availability

- E-prints Service

- Manuscript Podcast for convenient understanding

- Global attainment for your research

- Manuscript accessibility in different formats

( Pdf, E-pub, Full Text, Audio)

- Unceasing customer service

Track the below URL for one-step submission https://juniperpublishers.com/online-submission.php 